\title{
Effect of Relative Humidity on Sporulation of Fusarium oxysporum in Various Formulations and Effect of Water on Spore Movement Through Soil
}

\author{
J. A. Gracia-Garza and D. R. Fravel
}

\begin{abstract}
Biocontrol of Plant Diseases Laboratory, USDA, ARS, Beltsville Agricultural Research Center, Beltsville, MD 20705-2350.
Current address of J. A. Gracia-Garza: Agriculture \& Agri-Food Canada, Southern Crop Protection and Food Research Centre, P.O. Box 6000, Vineland Station, Ontario, Canada L0R 2E0. Accepted for publication 11 March 1998.
\end{abstract}

\begin{abstract}
Gracia-Garza, J. A., and Fravel, D. R. 1998. Effect of relative humidity on sporulation of Fusarium oxysporum in various formulations and effect of water on spore movement through soil. Phytopathology 88:544-549.

Fusarium oxysporum f. sp. erythroxyli is being investigated as a mycoherbicide for the narcotic plant coca. Sporulation of the fungus in seven formulations containing different organic substrates and movement of its propagules through soil were studied. The formulations were a granular wheat flour/kaolin (pesta); an extruded wheat and rice flour (C-6); and five alginate pellet products containing corn cobs, soybean hull fiber, canola meal, rice flour, or rice flour plus canola oil. Formulations were incubated at $25^{\circ} \mathrm{C}$ for 6 weeks in desiccators with various salt solutions to provide nine relative humidities (RH), ranging from $100 \%$ (pure deion-

plus canola oil as early as $24 \mathrm{~h}$ at $100 \%$ constant RH. Alginate pellets of rice plus canola oil and granular C-6 and pesta formulations consistently produced more microconidia, macroconidia, and CFU than the other four formulations at all $\mathrm{RH}$ tested. The C-6 formulation produced more propagules than the other formulations at low RH $(<53 \%)$. Canola meal pellets produced more spores than three other formulations when exposed to fluctuating RH (100 to 75\%). The effect of percolating water on spore movement through soil was studied using a plant-pathogenic isolate of $F$. oxysporum f. sp. niveum. To determine the effect of water percolation on propagule movement, formulations were placed on soil columns and artificial rain was applied. In general, 10 -fold fewer CFU were recovered at a 8 - to 10-cm depth compared with a 0 - to 2 -cm depth.
\end{abstract} ized water) to $0 \%$ (anhydrous $\mathrm{CaSO}_{4}$ ). Hyphae of $F$. oxysporum $\mathrm{f}$. sp. erythroxyli grew out of alginate pellets with canola meal, rice, and rice
Additional keywords: Erythroxylum coca.
Fusarium oxysporum Schlechtend.:Fr. f. sp. erythroxyli is currently causing an epidemic of wilt on the narcotic plant coca (Erythroxylum coca Lam. var. coca) in Peru and Hawaii (1,2,19, 20). This soilborne pathogen was isolated from diseased plants, and its potential as a mycoherbicide against coca is currently being evaluated. For $F$. oxysporum f. sp. erythroxyli to be useful as a mycoherbicide, it must be able to proliferate from a formulated preparation into soil.

Water in the soil environment can greatly affect microbial activity (10). Among many other factors, germination and sporulation of fungi, either on the phylloplane or in soil, depend on the availability of water. Likewise, dispersal of soilborne plant pathogens in soil is dependent on many factors including temperature, moisture, particle size distribution, aggregation of particles, and channels produced by activities of soil arthropods and small burrowing animals (5). Because $F$. oxysporum f. sp. erythroxyli infects plant roots, it must disperse from the formulation into the root zone to be effective. The objectives of this research were to (i) document the effect of constant and fluctuating relative humidity $(\mathrm{RH})$ on germination and sporulation of the mycoherbicide $F$.

Corresponding author: D. R. Fravel; E-mail address: dfravel@ asrr.arsusda.gov

Mention of a trademark or proprietary product does not constitute a guarantee or warranty of the product by the U.S. Department of Agriculture, and does not imply its approval to the exclusion of other products that may also be suitable.

Publication no. P-1998-0420-01R

This article is in the public domain and not copyrightable. It may be freely reprinted with customary crediting of the source. The American Phytopathological Society, 1998. oxysporum f. sp. erythroxyli when formulated with different organic substrates, and (ii) determine the effects of splashing water and percolating water on dispersal of propagules of this fungus through soil. To study the effect of percolating water through soil, $F$. oxysporum f. sp. niveum was substituted, because $F$. oxysporum f. sp. erythroxyli does not occur in the continental United States, and thus its use in research is restricted.

\section{MATERIALS AND METHODS}

Effect of constant RH on fungal germination and sporulation from formulations. Seven different formulations of $F$. $o x$ ysporum f. sp. erythroxyli were prepared using each of seven food bases: pesta (granular formulation prepared with wheat flour/ kaolin); C-6 (an extruded wheat and rice flour); and five alginate pellet products prepared with the food bases corn cob (Grit-o-Cob; The Anderson's, Maumee, OH), soybean hull fiber (Nutrisoy; Archer Daniels Midland Corp., Decatur, IL), canola meal, rice flour plus canola oil, or rice flour. Preparation of these formulations was described previously $(3,6,11,12)$. Briefly, pesta is a pasta-like process in which microbes are entrapped in a wheat gluten matrix. The fungus was grown in liquid culture. Biomass was collected, dried, and milled to pass through a 485- $\mu \mathrm{m}$-pore-size screen. Dough was prepared by mixing biomass, wheat flour, bulking agents, and water. The dough was rolled into thin sheets that were dried and ground to produce granules. For the C-6 formulation, rice flour and vermiculite were autoclaved. After cooling, vermiculite, wheat flour, canola oil, and dried, milled biomass were added. The dough was kneaded and extruded through a benchtop granulator (LCI, Charlotte, NC). Formulations were stored in plastic containers at $4^{\circ} \mathrm{C}$ and were used within 4 months after preparation. 
These formulations were incubated for 6 weeks in sealed desiccators over water, saturated salt slurries, or a desiccant to establish and maintain nine different $\mathrm{RH}$. These included 100\% (pure deionized water), $96 \%\left(\mathrm{KH}_{2} \mathrm{PO}_{4}\right), 75 \%(\mathrm{NaCl}), 53 \%\left(\mathrm{Mg}\left(\mathrm{NO}_{3}\right)_{2}\right)$, $43 \%\left(\mathrm{~K}_{2} \mathrm{CO}_{3}\right), 33 \%\left(\mathrm{MgCl}_{2}\right), 12 \%(\mathrm{LiCl}), 7 \%(\mathrm{NaOH})$, and $0 \%$ (anhydrous $\left.\mathrm{CaSO}_{4}\right) \mathrm{RH}(7,25,26)$. Desiccators were placed in an incubator maintained at $25^{\circ} \mathrm{C} \pm 0.2^{\circ} \mathrm{C}$ with a 14 -h photoperiod provided by fluorescent light. After $48 \mathrm{~h}$ for equilibration of salt solutions, formulations (50 to 75 granules per dish) were placed inside the desiccators on uncovered 3.5-cm-diameter petri dishes. Dishes were arranged randomly within each desiccator, with three replicates per treatment. Without opening the desiccators, every $24 \mathrm{~h}$, salt solutions were stirred using a magnetic stir plate to prevent formation of a thin layer of salt on the surface of the solution, which would interfere with vapor exchange. After 1, 2, 4, and 6 weeks of incubation, desiccators were opened briefly to remove $0.01 \mathrm{~g}$ of each formulation. Each sample was placed in a $1.5-\mathrm{ml}$ microcentrifuge tube containing $1 \mathrm{ml}$ of sterile distilled water. Tubes were vortexed for $1 \mathrm{~min}$ and the water examined microscopically with a hemacytometer to determine the number of microconidia, macroconidia, and chlamydospores. In addition, 10-fold dilutions were made, and a 1-ml aliquot was plated on a Fusarium spp. semiselective medium (FSM) (16). Plates were incubated at $22^{\circ} \mathrm{C}$ for 5 days under fluorescent light, and the number of Fusarium colonies was counted and recorded as CFU per $0.01 \mathrm{~g}$ of formulation. The experiment was repeated once.

Effect of fluctuating RH on fungal germination and sporulation from formulations. The effect of fluctuation in $\mathrm{RH}$ on sporulation of $F$. oxysporum f. sp. erythroxyli was studied using four formulations: granular C-6, and alginate pellets of canola meal, rice plus canola oil, and rice. These formulations were chosen because they represented different sporulation responses at constant RH. Formulations were placed in the desiccators as described above. Petri dishes containing the formulations were transferred every $72 \mathrm{~h}$ from one desiccator to another, with a different $\mathrm{RH}$ for the entire 6-week sampling period. Treatments consisted of moving the formulations back and forth from $100 \%$ to $75 \% \mathrm{RH}$, from 100 to $53 \% \mathrm{RH}$, from 100 to $12 \% \mathrm{RH}$, from 100 to $0 \% \mathrm{RH}$, from 75 to $53 \% \mathrm{RH}$, from 75 to $12 \% \mathrm{RH}$, from 75 to $0 \% \mathrm{RH}$, from 53 to $12 \%$ $\mathrm{RH}$, from 53 to $0 \% \mathrm{RH}$, and from 12 to $0 \% \mathrm{RH}$. Formulations were completely randomized within each desiccator, with three replicates per treatment. These ranges were chosen to include possible extremes to which formulations could be exposed under natural conditions. Formulations were sampled at 1, 2, 4, and 6 weeks of incubation as in the previous experiment. The experiment was repeated once.

Effect of water percolation on dispersal of conidia through soil columns. F. oxysporum f. sp. erythroxyli could not be used for this study, because the rain simulation device is permanently located in a greenhouse not approved for working with nonindigenous pathogens. Thus, an ultraviolet light-induced, orange-colored mutant strain of $F$. oxysporum f. sp. niveum from watermelon (17) was used in tests conducted in Beltsville, MD, to distinguish the test fungus from indigenous $F$. oxysporum found in soil. This strain is comparable to the wild-type strain in spore size and morphology, growth, sporulation, survival in soil, and pathogenicity (17). Granules of the C-6 formulation were placed on petri plates lined with sterile, moist filter paper, covered with the lid of the petri dish, and incubated for 4 days to allow sporulation. Most $(>99 \%)$ of the spores produced were microconidia.

Movement of spores through soil was studied using each of four soils: Galestown gravelly loamy sand (GGLS), $\mathrm{pH} 5.8$, bulk density (BD) $1.35 \mathrm{~g} / \mathrm{cm}^{3}$, sand $77.8 \%$, silt $12.6 \%$, clay $9.6 \%$, organic matter (OM) $0.6 \%$, and cation exchange capacity (CEC) 4.0; Hatboro loamy sand (HLS), $\mathrm{pH} 4.5$, BD $1.09 \mathrm{~g} / \mathrm{cm}^{3}$, sand $59.4 \%$, silt $28.8 \%$, clay $11.8 \%$, OM $3.2 \%$, and CEC 4.5; red clay subsoil (RC), $\mathrm{pH}$ 4.4 , BD $1.21 \mathrm{~g} / \mathrm{cm}^{3}$, sand $17.7 \%$, silt $40.1 \%$, clay $42.2 \%$, OM $0.0 \%$, and CEC 2.4; and Halii sandy clay loam (HSCL), pH 5.2,
BD $1.10 \mathrm{~g} / \mathrm{cm}^{3}$, sand $33.1 \%$, silt $44.0 \%$, clay $32.9 \%$, and OM $6.1 \%$. The GGLS, HLS, and RC soils were from Beltsville, MD, and were used immediately after collection. The HSCL soil was collected from an area on the island of Kauai, HI, known to have coca wilt $(13,22)$ and was stored at $4{ }^{\circ} \mathrm{C}$ for up to 3 months before use. All soils were air-dried at room temperature for 1 day. Soil columns were constructed by taping together transparent plastic rings $(2-\mathrm{cm}$ tall $\times 2-\mathrm{cm}$ inside diameter) to form a 10 -cm-tall column. Columns were filled with soil on the day the experiment was conducted. Sporulating formulation was placed onto the surface of these soil columns, 20 granules per column, with three replicates per treatment. Simulated rain was applied to the soil columns using a rain apparatus (15). All experiments in which artificial rain was applied were conducted in Beltsville, MD, and used $F$. oxysporum f. sp. niveum. Simulated rain was applied at the rate of $1 \mathrm{~mm} \mathrm{~h}^{-1}$ until the water percolating through the soil had reached the bottom of the column. Water reached the bottom of most columns within 5 min. However, for soil with a high content of clay (i.e., RC), a pause in the application of rain was required to allow water to percolate through the soil without overflowing. Column rings were separated, and soil from each ring was placed in a 250-ml Erlenmeyer flask with $100 \mathrm{ml}$ of sterile distilled water and agitated on a benchtop shaker (L.E.D. Orbit Shaker; Labline Instruments, Inc., Melrose Park, IL) for $30 \mathrm{~min}$ at $150 \mathrm{rpm}$. Ten-fold dilutions were made, and 1-ml aliquots were plated on FSM. Plates were incubated as described previously and the number of CFU recorded. Control treatments consisted of granules without the orange-colored F. oxysporum f. sp. niveum strain. Soil columns were arranged in a completely randomized design. The experiment was repeated once.

In the last experiment, granules on the filter paper produced mainly microconidia. An additional experiment was performed with formulations producing mainly macroconidia. The experiment was identical to the previous experiment, except that 20 granules of C-6 per replicate containing the orange-mutant $F$. oxysporum $\mathrm{f}$. sp. niveum strain were placed on the surface of GGLS and HSCL soils and misted with tap water once a day to provide moisture for germination. The granules were not covered.

Tests on spore movement through soil were conducted using natural, rather than simulated, rain. At a field site at Kauai, HI, where precipitation occurs intermittently throughout the day, 20 granules of C-6 containing $F$. oxysporum f. sp. erythroxyli were set on the surface of the undisturbed soil. The petri dish was removed daily to mist the granules to enhance production of macroconidia. Granules without the fungus were also included as controls. Treatments were arranged in a completely randomized design. Granules on the soil surface were covered with a petri plate for 5 days. On the sixth day, after the fungus had sporulated on the granules, the petri plate was removed for $5 \mathrm{~min}$ when natural rainfall was approximately $0.1 \mathrm{~mm} \mathrm{~h}^{-1}$. Rain intensity was estimated by determining drop size and frequency of drop fall with the aid of watersensitive paper (Ciba-Geigy Ltd., Basel, Switzerland [Spraying Systems Co., Wheaton, IL]) and later confirmed with field readings from a meteorological station present where the tests were conducted. After the rain stopped (usually after 10 to $15 \mathrm{~min}$ ), granules were removed from the soil surface, and then a soil core (2-cm wide $\times 8$-cm tall) was withdrawn. The core was separated into 4-cm segments, and soil dilutions were made. Fungal populations were estimated as described previously. The experiment was repeated once.

Statistical analysis. All experiments were repeated at least once, and each experiment contained three replicates. Variances among experiments were homogenous, and results from one representative test are presented. Analysis of variance was carried out, and differences among means were estimated using Fisher's protected least significant difference test (23). The effect of successive sampling dates was analyzed by repeated measure analysis of variance. Statistical analyses used the general linear model procedures of SAS (Statistical Analysis System, Cary, NC). Regression anal- 
ysis was used in experiments dealing with water dispersal of propagules in soil as an estimate of relative rates of spore movement among soil types. Linear regression was conducted on $\log _{10}$ values of propagule counts at increasing soil depths, and regression slopes were compared among different soil types by analysis of covariance.

\section{RESULTS}

Effect of constant RH on fungal germination and sporulation from formulations. Hyphae of F. oxysporum f. sp. erythroxyli grew from alginate pellets containing canola meal, rice, and rice plus canola oil as early as $24 \mathrm{~h}$ after constant exposure to $100 \% \mathrm{RH}$.

By 7 days, all formulations sporulated at $100 \%$ constant RH. At a constant RH of $100 \%$, significantly more CFU (microconidia, macroconidia, and mycelial pieces) were produced on the pesta and canola formulations than on other formulations at the 1-week sampling $(P \leq 0.05)$. At the 2 - and 4-week samplings, significantly more CFU were produced on the pesta formulation than on any other formulations tested, and at 6 weeks, significantly more CFU were produced on the pesta and corn cob formulation than on

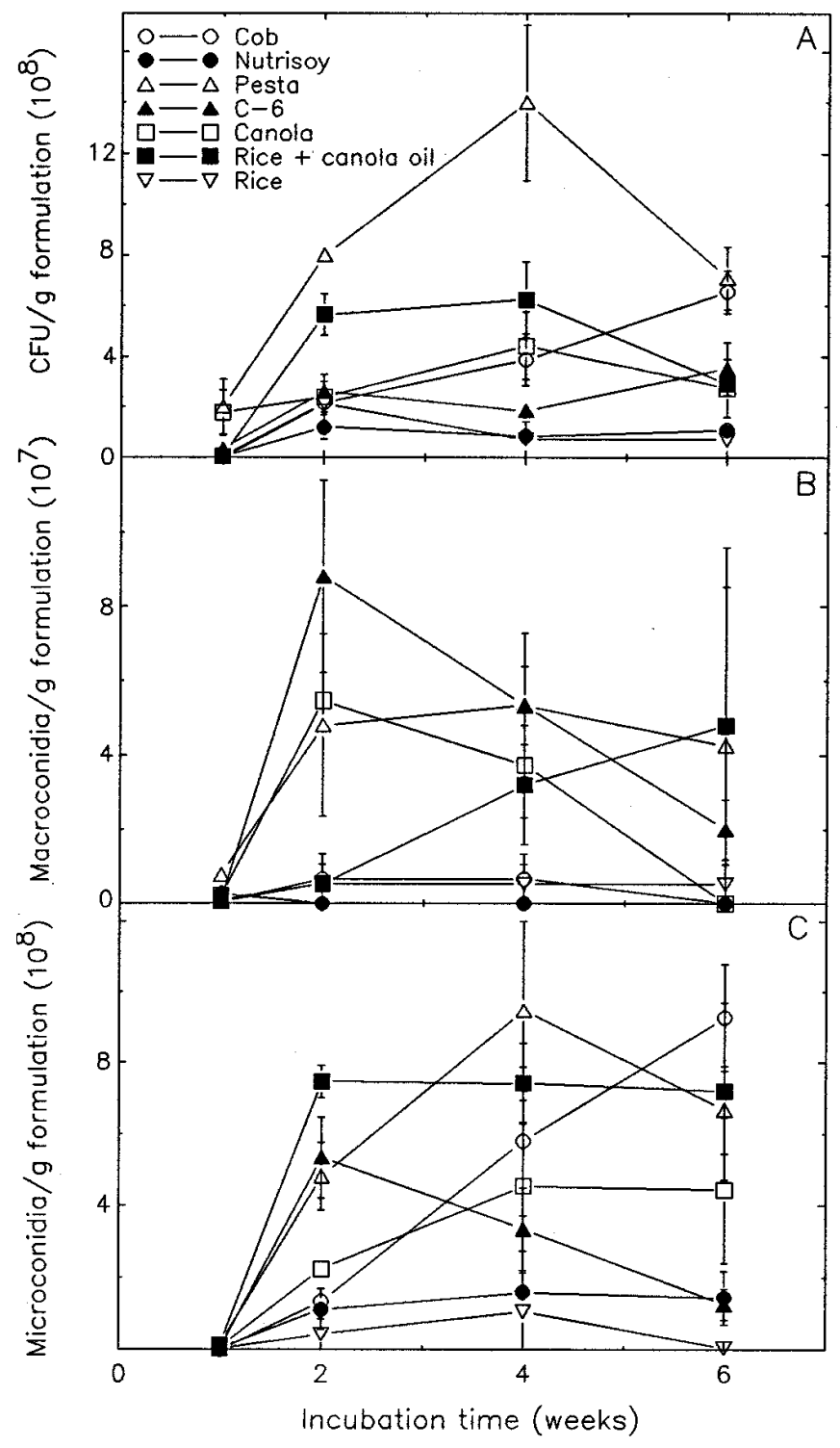

Fig. 1. Production of $\mathbf{A}, \mathbf{C F U} ; \mathbf{B}$, macroconidia; and $\mathbf{C}$, microconidia from several formulations of the mycoherbicide Fusarium oxysporum f. sp. erythroxyli incubated at $100 \%$ constant relative humidity at $25^{\circ} \mathrm{C}$. Bars represent standard error of the mean. Data are from a single representative test and are the mean of three replicates per treatment. other formulations $(P \leq 0.05)$. In general, for all propagule types, the Nutrisoy formulation produced the lowest number of propagules. In most cases, chlamydospores were at undetectable levels.

In general, all formulations produced greater numbers of microconidia than macroconidia. Approximately 10-fold fewer macroconidia than microconidia were produced in all formulations (Fig. $1 \mathrm{~B}$ and $\mathrm{C}$ ). Initially, the greatest number of macroconidia was produced on the Nutrisoy formulation (Fig. 1B). After 6 weeks, the greatest number of macroconidia were produced on the pesta and rice plus canola oil formulations. Production of macroconidia from the C- 6 formulation peaked by the second week $\left(8.8 \times 10^{7}\right.$ per $g$ of formulation) and decreased over time $\left(2 \times 10^{7}\right.$ per $g$ of formulation) (Fig. 1B). In contrast, the alginate rice plus canola oil formulation produced macroconidia more slowly, but production increased over time with the highest number observed after 6 weeks $\left(5 \times 10^{7}\right.$ per $\mathrm{g}$ of formulation $)$. Pesta also produced a large amount of macroconidia, but numbers remained relatively constant over time $\left(5 \times 10^{7}\right.$ per $\mathrm{g}$ of formulation). C- 6 and pesta formulations produced the greatest cumulative number of macroconidia after incubation for 6 weeks at $100 \%$ constant RH. After 2 weeks of incubation, the number of microconidia produced on the rice plus canola oil was significantly greater than from any other treatment (Fig. 1C). The number of microconidia produced on the C-6 and pesta formulations was significantly less than the number produced on the rice plus canola oil, but was significantly greater than from other treatments. The number of microconidia produced was greatest in the alginate formulation with rice plus canola oil after 2 weeks $\left(7 \times 10^{8}\right.$ per $g$ of formulation), and this level of microconidial production was maintained throughout the 6 weeks of incubation, while the number of microconidia increased on the corn cob and canola meal alginate formulations, and increased then decreased on pesta (Fig. 1C). Nutrisoy, C-6, and rice formulations produced significantly fewer microconidia after 6 weeks than did the rest of the formulations at a constant RH of $100 \%$.

As the $\mathrm{RH}$ decreased, production of mycelium and conidia also decreased. At RH of $75 \%$ or lower, production of conidia was undetectable in all formulations (data not shown). However, some CFU were still detected at 12\% RH in C-6 (Table 1) and pesta formulations (data not shown). At low $\mathrm{RH}$, microscopic observations revealed predominantly hyphal fragments. Thus, CFU counts recorded for low RH primarily represent fragments of mycelium broken off from the surface of the granules during vortexing.

Effect of fluctuating RH on fungal germination and sporulation from formulations. For all formulations tested, microconidial and macroconidial counts averaged about 10-fold less when

TABLE 1. Production of microconidia, macroconidia, and CFU from the C-6 formulation of the mycoherbicide Fusarium oxysporum f. sp. erythroxyli when exposed to a range of constant relative humidities

\begin{tabular}{lccr}
\hline \multirow{2}{*}{$\begin{array}{l}\text { Relative } \\
\text { humidityw }(\%)\end{array}$} & \multicolumn{3}{c}{ Propagules per gram of formulation } \\
\cline { 2 - 4 } & Microconidia $\left(\times 10^{6}\right)$ & Macroconidia $\left(\times 10^{5}\right)$ & $\mathrm{CFU}^{\mathrm{x}}\left(\times 10^{6}\right)$ \\
\hline 100 & $533.3^{\mathrm{y}} \mathrm{a}^{\mathrm{z}}$ & $880.0 \mathrm{a}$ & $260.3 \mathrm{a}$ \\
96 & $0.0 \mathrm{~b}$ & $173.3 \mathrm{~b}$ & $41.7 \mathrm{~b}$ \\
75 & $0.0 \mathrm{~b}$ & $0.0 \mathrm{c}$ & $0.1 \mathrm{~b}$ \\
53 & $0.0 \mathrm{~b}$ & $0.0 \mathrm{c}$ & $0.0 \mathrm{~b}$ \\
43 & $0.0 \mathrm{~b}$ & $0.0 \mathrm{c}$ & $0.4 \mathrm{~b}$ \\
33 & $0.0 \mathrm{~b}$ & $0.0 \mathrm{c}$ & $3.2 \mathrm{~b}$ \\
12 & $0.0 \mathrm{~b}$ & $0.0 \mathrm{c}$ & $4.7 \mathrm{~b}$ \\
7 & $0.0 \mathrm{~b}$ & $0.0 \mathrm{c}$ & $0.8 \mathrm{~b}$ \\
0 & $0.0 \mathrm{~b}$ & $0.0 \mathrm{c}$ & $0.0 \mathrm{~b}$ \\
\hline
\end{tabular}

${ }^{\mathrm{w}}$ Constant relative humidity established in desiccators using saturated salt solutions.

${ }^{x} \mathrm{CFU}$ includes macroconidia, microconidia, and hyphal fragments.

${ }^{y}$ Mean values from three replicates after 2 weeks of incubation at constant relative humidity. Treatments were completely randomized within closed desiccators for each relative humidity. Data are from a single representative test.

${ }^{z}$ Values followed by the same letter do not differ from each other according to Duncan's multiple range test $(P \leq 0.05)$. 
incubated at a fluctuating RH (100 to 75\%) than when incubated at a constant $\mathrm{RH}$ of $100 \%$. The number of microconidia recovered from formulations incubated with fluctuating RH (100 to 75\%) was relatively constant over the 6-week incubation period for each of the formulations (Fig. 2A). The number of macroconidia in the canola meal-alginate formulation increased over time, reaching the highest production after 6 weeks $\left(6 \times 10^{5}\right.$ per $g$ of formulation $)$ (Fig. 2B). Rice, rice plus canola oil, and C- 6 produced $1 \times 10^{5}$ to $3 \times 10^{5}$ macroconidia per $\mathrm{g}$ of formulation at all sampling times. In contrast to the other measurements, CFU recorded for most of the formulations at fluctuating $\mathrm{RH}$ was similar to $\mathrm{CFU}$ at constant RH (Fig. 2C), because of the presence of viable mycelial fragments observed in the sample, which resulted in colony formation. As with constant RH, chlamydospores were not detected. Under the conditions of this test, the canola formulation produced the largest number of conidia (microconidia and macroconidia) and the highest CFU counts at fluctuating RH when the formulation was incubated at $100 \% \mathrm{RH}$ at least part of the time (data not shown). However, the C-6 formulation was the only formulation to produce $\mathrm{CFU}$ at lower fluctuating $\mathrm{RH}$ (i.e., 53 to $0 \%$ ) (Table 2).

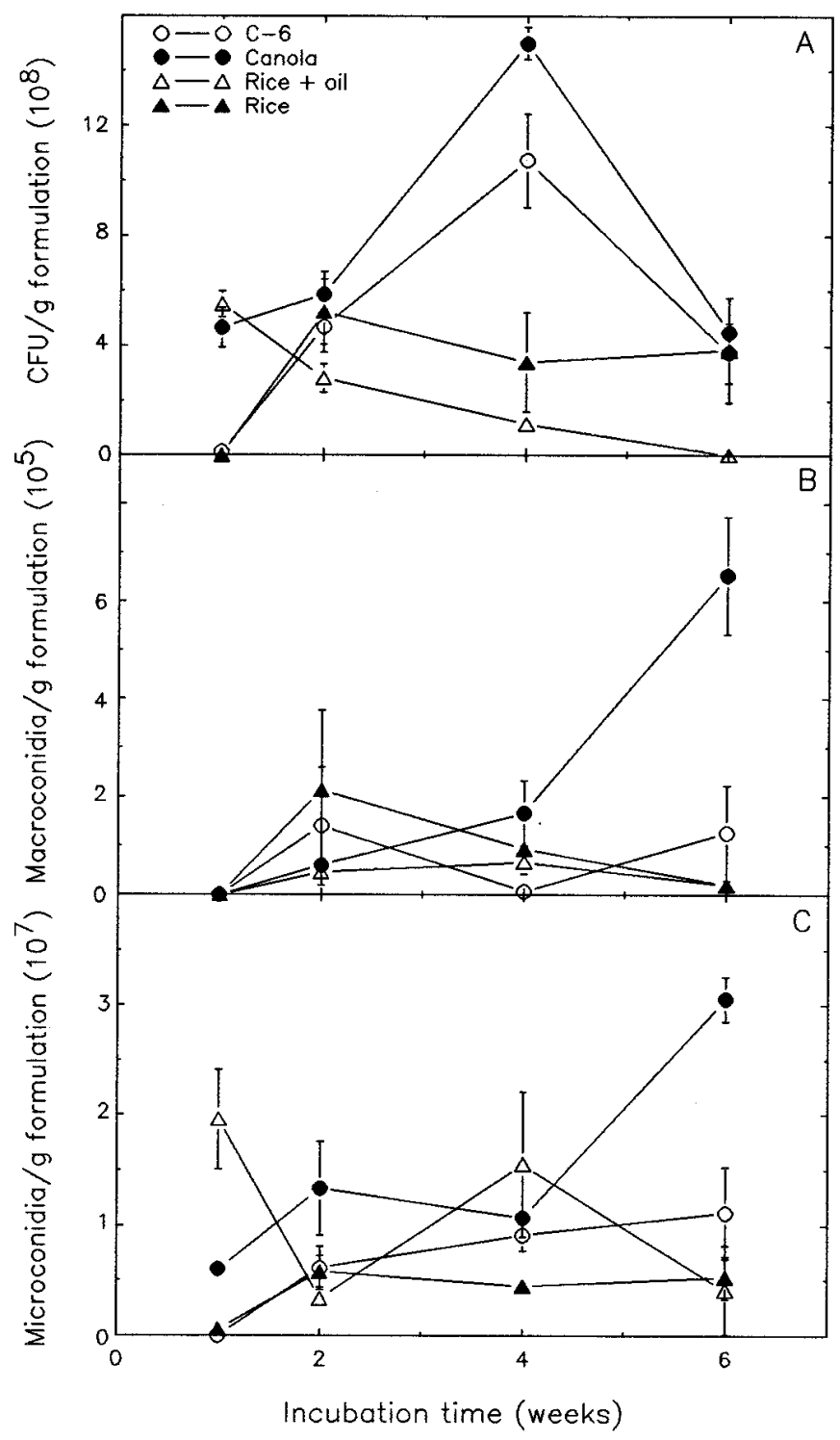

Fig. 2. Production of $\mathbf{A}, \mathbf{C F U} ; \mathbf{B}$, macroconidia; and $\mathbf{C}$, microconidia from several formulations of the mycoherbicide Fusarium oxysporum f. sp. erythroxyli incubated at a fluctuating relative humidity $(100$ to $75 \%)$ at $25^{\circ} \mathrm{C}$. Bars represent standard error of the mean. Data are from a single representative test and are the mean of three replicates per treatment.
Effect of water percolation on dispersal of conidia through soil. After a 4-day incubation on moist filter paper, most of the propagules observed on the formulation were microconidia $(>99 \%)$. Thus, movement of F. oxysporum in these tests was mainly that of the microconidia and mycelial fragments released from the formulation by the impact of water drops from artificial rain. No significant differences were observed among the total number of CFU recovered from the different soils used in these tests. In all soils, most of the CFU were recovered from the top $2 \mathrm{~cm}$ of the column $(\boldsymbol{P} \leq 0.01)$ (Table 3$)$. However, some propagules did move through the soil, and in most instances, CFU were recovered from all column segments. In the RC soil, nearly all of the propagules were retained within the upper $2 \mathrm{~cm}$, although occasionally some $\mathrm{CFU}$ were recorded at a depth of $4 \mathrm{~cm}$. Linear regression analysis of CFU at increasing soil depths indicated that propagule movement was significantly greater $(P \leq 0.05)$ in the Hawaiian soil compared with the other soils (Table 3 ). However, it is important to observe that because of the low counts at the lower levels for GGLS and HLS soils, movement of propagules through these

TABLE 2. Production of microconidia, macroconidia, and CFU from the C-6 formulation of the mycoherbicide Fusarium oxysporum f. sp. erythroxyli when exposed to a range of fluctuating relative humidities

\begin{tabular}{lccc}
\hline \multirow{2}{*}{$\begin{array}{l}\text { Relative } \\
\text { humidity }(\%)\end{array}$} & \multicolumn{3}{c}{ Propagules per gram of formulation } \\
\cline { 2 - 4 } & Microconidia $\left(\times 10^{5}\right)$ & Macroconidia $\left(\times 10^{5}\right)$ & $\mathrm{CFU}\left(\times 10^{6}\right)$ \\
\hline 100 to 75 & $61.3^{\mathrm{y}} \mathrm{a}^{\mathrm{z}}$ & $14.0 \mathrm{a}$ & $468.7 \mathrm{a}$ \\
100 to 53 & $2.7 \mathrm{~b}$ & $0.0 \mathrm{~b}$ & $16.4 \mathrm{~b}$ \\
100 to 12 & $4.7 \mathrm{~b}$ & $0.0 \mathrm{~b}$ & $33.3 \mathrm{~b}$ \\
100 to 0 & $8.0 \mathrm{~b}$ & $2.7 \mathrm{ab}$ & $45.7 \mathrm{~b}$ \\
75 to 53 & $2.0 \mathrm{~b}$ & $0.0 \mathrm{~b}$ & $0.3 \mathrm{~b}$ \\
75 to 12 & $1.3 \mathrm{~b}$ & $0.0 \mathrm{~b}$ & $0.0 \mathrm{~b}$ \\
75 to 0 & $2.7 \mathrm{~b}$ & $0.0 \mathrm{~b}$ & $0.0 \mathrm{~b}$ \\
53 to 12 & $0.0 \mathrm{~b}$ & $0.0 \mathrm{~b}$ & $0.0 \mathrm{~b}$ \\
53 to 0 & $1.3 \mathrm{~b}$ & $0.0 \mathrm{~b}$ & $0.0 \mathrm{~b}$ \\
12 to 0 & $1.3 \mathrm{~b}$ & $0.0 \mathrm{~b}$ & $0.0 \mathrm{~b}$ \\
\hline
\end{tabular}

${ }^{x}$ Level of relative humidity was obtained in closed desiccators using saturated salt solutions. Formulations were moved from one relative humidity to the other every $72 \mathrm{~h}$ for the entire 6-week test period. Data are shown for the 2-week sampling.

y Mean values from three replicates after 2 weeks of incubation at fluctuating relative humidity. Data are from a single representative test.

${ }^{\mathrm{z}}$ Treatments followed by different letters within a column differ according to a protected least significant difference test $(P \leq 0.05)$.

TABLE 3. Effect of water percolation ${ }^{\mathrm{u}}$ on the dispersal of Fusarium oxysporum $\mathrm{f}$. sp. niveum formulated as C-6 and incubated on moist filter paper through different soils

\begin{tabular}{lcccccc}
\hline & \multicolumn{6}{c}{ Column depth (cm) } \\
\cline { 2 - 7 } Soil type $^{\mathrm{v}}$ & $0-2$ & $2-4$ & $4-6$ & $6-8$ & $8-10$ & Slope $^{\mathrm{w}}$ \\
\hline GGLS & $24.8^{\mathrm{x}} \mathrm{a}^{\mathrm{y}}$ & $5.0 \mathrm{ab}$ & $2.6 \mathrm{ab}$ & $0.7 \mathrm{~b}$ & $0.2 \mathrm{a}$ & -5.6 \\
HLS & $27.4 \mathrm{a}$ & $8.2 \mathrm{a}$ & $3.7 \mathrm{a}$ & $4.3 \mathrm{a}$ & $3.0 \mathrm{a}$ & -4.7 \\
RC & $8.2 \mathrm{a}$ & $0.0 \mathrm{~b}$ & $0.0 \mathrm{c}$ & $0.0 \mathrm{~b}$ & $0.0 \mathrm{a}$ & -4.2 \\
HSCL & $8.9 \mathrm{a}$ & $3.2 \mathrm{ab}$ & $1.5 \mathrm{bc}$ & $2.2 \mathrm{ab}$ & $4.5 \mathrm{a}$ & NS $^{\mathrm{z}}$ \\
\hline
\end{tabular}

u Intensity of simulated rain was $1.0 \mathrm{~mm} \mathrm{~h}^{-1}$.

${ }^{v}$ GGLS = Galestown gravelly loamy sand (bulk density $[\mathrm{BD}]=1.35 \mathrm{~g} / \mathrm{cm}^{3}$ ), HLS = Hatboro loamy sand $\left(B D 1.09 \mathrm{~g} / \mathrm{cm}^{3}\right), \mathrm{RC}=$ red clay subsoil $(\mathrm{BD}$ $\left.1.21 \mathrm{~g} / \mathrm{cm}^{3}\right)$, and HSCL $=$ Halii sandy clay loam $\left(\right.$ BD $\left.1.10 \mathrm{~g} / \mathrm{cm}^{3}\right)$. Soils were placed in transparent plastic columns $2 \times 10-\mathrm{cm}$ tall. Matric potential of all soils was approximately $-10 \mathrm{HPa}$ when soil was placed in columns. Columns were completely randomized for exposure to simulated rain.

${ }^{w}$ Linear regression slope value. Regression was based on $\log _{10}$-transformed propagule counts, and differences among soil types were determined by analysis of covariance.

x Values represent the number of CFU of $F$. oxysporum $\mathrm{f}$. sp. niveum $\left(\times 10^{2}\right)$ per $g$ of dry soil. Data are the mean values of three replicates from one representative test.

y Treatments followed by different letters within a column differ according to Fisher's protected least significant difference test $(P \leq 0.05)$.

${ }^{\mathrm{z}} \mathrm{NS}=$ nonsignificant. Movement of propagules through the Hawaiian soil was statistically different $(P \leq 0.05)$ than through other soils tested. 
soils was not significantly different than those from RC soil, even when no CFU were recovered at depths below $2 \mathrm{~cm}$ in the latter soil (Table 3). Granules exposed to soil produced mainly macroconidia (>90\%), while those in the preceding test, exposed to filter paper (which stayed moist for a longer period of time), produced mainly microconidia ( $>99 \%$ ). C-6 granules without $F$. oxysporum f. sp. niveum were used as controls.

Granules of the C- 6 formulation incubated on the soil surface produced mainly macroconidia ( $>90 \%)$. More CFU were detected on GGLS soil than on HSCL soil, and this difference was observed in all tests. More CFU were found on the top $2 \mathrm{~cm}$ of both soils (Table 4). However, regression analysis indicated that movement of the propagules through soil was different in both soils (Table 4).

When movement of spores in an artificial environment using HSCL soil was compared with movement of spores in undisturbed soil on the island of Kauai, no significant differences were found. In the undisturbed soil, CFU were 31.73 and $1.33 \times 10^{4}$ at 0 to 4 and 4 to $8 \mathrm{~cm}$, respectively, whereas in the artificial environment, CFU were 51.48 and $9.63 \times 10^{4}$. The ratio of the $\log _{10}$ values of $\mathrm{CFU}$ found in the artificial environment between the upper (0 to 4 ) and lower (4 to 8) segments of the column was 1.91, while movement under natural rainfall and undisturbed soil showed a ratio of 1.52 . This difference was not statistically different $(P>0.05)$.

\section{DISCUSSION}

Lowering water activity has been used to prolong shelf life of biocontrol agents in formulations (7). Our study addressed a different aspect of water activity, namely, at what levels of RH could F. oxysporum f. sp. erythroxyli sporulate from various formulations. This characteristic could then be considered, along with other formulation characteristics, in deciding which formulation would be most appropriate. The C-6 formulation produced more CFU at lower $\mathrm{RH}$, constant or fluctuating, than the other formulations tested. The ability to produce $\mathrm{CFU}$ at moderate $\mathrm{RH}$ has advantages and disadvantages. The advantage is that the C-6 formulation may be more suitable than other formulations in areas where moderate dry conditions prevail. Although E. coca is usually grown in regions with high precipitation, even on the island of Kauai where some of the highest precipitation on earth is registered, there are short periods with little or no precipitation. The disadvantage is that the ability to sporulate at low RH may make this formulation undesirable from the point of view of commercialization, because it may shorten shelf life (7).

TABLE 4. Effect of water percolation ${ }^{v}$ on the dispersal of propagules of Fusarium oxysporum $\mathrm{f}$. $\mathrm{sp}$. niveum from the C-6 formulation when germinated on the soil surface through two soils

\begin{tabular}{lcccccc}
\hline & \multicolumn{6}{c}{ Column depth $(\mathrm{cm})$} \\
\cline { 2 - 6 } Soil type $^{\mathrm{w}}$ & \multicolumn{1}{c}{$0-2$} & $2-4$ & $4-6$ & $6-8$ & $8-10$ & Slope $^{\mathrm{x}}$ \\
\hline GGLS & $67.8^{\mathrm{y}} \mathrm{a}^{\mathrm{z}}$ & $12.4 \mathrm{a}$ & $6.8 \mathrm{a}$ & $3.1 \mathrm{a}$ & $2.6 \mathrm{a}$ & -4.1 \\
HSCL & $17.9 \mathrm{~b}$ & $3.5 \mathrm{~b}$ & $3.2 \mathrm{a}$ & $3.0 \mathrm{a}$ & $1.6 \mathrm{a}$ & -2.1 \\
\hline
\end{tabular}

v Intensity of simulated rain was $1.0 \mathrm{~mm} \mathrm{~h}^{-1}$.

${ }^{\mathrm{w}}$ GGLS = Galestown gravelly loamy sand (bulk density $[\mathrm{BD}]=1.35 \mathrm{~g} / \mathrm{cm}^{3}$ ), and HSCL = Halii sandy clay loam $\left(B D 1.10 \mathrm{~g} / \mathrm{cm}^{3}\right)$. Soils were placed in transparent plastic columns $2 \times 10-\mathrm{cm}$ tall. Matric potential of both soils was approximately $-10 \mathrm{HPa}$ when soil was placed in columns. Columns were completely randomized for exposure to simulated rain.

${ }^{x}$ Linear regression slope value. Regression was based on $\log _{10}$-transformed propagule counts, and differences among soil types were determined by analysis of covariance.

y Values represent the number of CFU of F. oxysporum $\mathrm{f}$. sp. niveum $\left(\times 10^{2}\right)$ per $g$ of dry soil. Data are the mean values of three replicates from one representative test.

$\mathrm{z}$ Treatments followed by different letters within a column differ according to Fisher's protected least significant difference test $(P \leq 0.05)$.
Formulation can greatly affect many attributes of a biocontrol product including the efficacy, ease and safety of application, and shelf life $(8,9)$. In our study, the amount of sporulation by $F$. oxysporum f. sp. erythroxyli on the various formulations and the type of propagules produced were affected by the food base in the formulation. While growth from the canola formulation occurred within $24 \mathrm{~h}$ at constant $\mathrm{RH}$, this formulation produced mainly mycelium, in contrast to the C-6, pesta, and rice plus canola oil formulations, which produced microconidia and macroconidia. Production of macroconidia is desirable because they may produce chlamydospores that allow the fungus to overcome adverse environmental conditions. Chlamydospores are thought to be important for the establishment of $F$. oxysporum f. sp. erythroxyli in soil, because they are survival structures. Hebbar et al. $(11,12)$ reported that the C-6 formulation produced more secondary chlamydospores of $F$. oxysporum f. sp. erythroxyli after incubation of the formulation granules on water agar for 2 weeks than did other formulations tested.

Dispersal of fungal propagules in soil water is assumed to be affected by size and shape of the spore, electrical charge of the spore, as well as by physical properties of soil such as pore size and electrical charge of the soil particles $(14,18,21,24)$. Wallace (24) stated that "soil pathogens are probably not dispersed more than a few centimeters by percolating water and even then it is mostly downward." Hepple (14) concluded that the rate of infiltration of water through soil is seldom high enough to move fungal spores. The hydrophobic nature of some spores may account for their low rate of passive transport within the soil profile (21). Similarly, Burke (4) concluded that "dissemination of the pathogen is largely limited to washing over the soil surface" and that "propagules of the Fusarium apparently are rapidly filtered out as water percolates through soil." Recently, Natsch et al. (18) measured the movement of cells of Pseudomonas fluorescens through soils following sprinkling to simulate heavy rain. The bacterium was rapidly transported to deeper soil layers $(150 \mathrm{~cm})$ through channels of preferential flow. The transport was affected by cultural practice.

Transport of spores by runoff water may be significant. In some samples obtained from puddles after a heavy rain in Kauai, we were able to recover large numbers $\left(6 \times 10^{2} \mathrm{ml}^{-1}\right)$ of CFU of $F$. oxysporum f. sp. erythroxyli (J. A. Gracia-Garza, unpublished data). Long-distance transport of the pathogen by running water is facilitated by the hydrophobic nature of the spores and the fact that plantations of $E$. coca are often located on steep hillsides. Further research on the performance of these formulations under field environments and with other potential mycoherbicides is currently being studied. Additional information on the performance of these formulations under different regimes of temperature and $\mathrm{RH}$ will be useful for the determination of an application strategy.

\section{ACKNOWLEDGMENTS}

We thank P. K. Hebbar and S. Poch (Biocontrol of Plant Diseases Laboratory, Plant Sciences Institute), and W. J. Connick, Jr. (USDA, ARS, New Orleans) for providing the formulations for these tests; A. M. Sadeghi (Environmental Chemistry Laboratory) for allowing us to use the facilities in his laboratory; R. P. Larkin for providing the orange mutant of Fusarium oxysporum f. sp. niveum; and L. Kennaly for her excellent technical assistance. We thank C. L. Campbell, North Carolina State University, Raleigh, for administration of the appointment of J. A. Gracia-Garza as a visiting scientist in the Biocontrol of Plant Diseases Laboratory.

\section{LITERATURE CITED}

1. Arévalo, E., Zúñiga, L., and Cabezas, O. 1994. Coca plant wilt and its ecological implications in Alto Huallaga. Page 17 in: Resumenes $13^{\circ}$ Congreso Peruano de Fitopatología. Asociación Peruana de Fitopatología, Tingo María, Perú.

2. Bailey, B. A., Hebbar, P. K., and Lumsden, R. D. 1996. Biocontrol of Erythroxylum coca in the field with a formulation of Fusarium oxysporum f. sp. erythroxyli. Phytopathology 86:S9. 
3. Bailey, B. A., Hebbar, P. K., Strem, M., Darlington, L. C., and Lumsden, R. D. 1997. An alginate prill formulation for Fusarium oxysporum Schlechtend.:Fr. f. sp. erythroxyli for biocontrol of Erythroxylum coca var. coca. Biocontrol Sci. Technol. 7:423-435.

4. Burke, D. W. 1965. The near immobility of Fusarium solani f. phaseoli in natural soils. Phytopathology 55:1188-1190.

5. Campbell, C. L., and Benson, D. M. 1994. Spatial aspects of the development of root disease epidemics. Pages 195-234 in: Epidemiology and Management of Root Diseases. C. L. Campbell and D. M. Benson, eds. Springer-Verlag, Berlin.

6. Connick, W. J., Jr., Boyette, C. D., and McAlpine, J. R. 1991. Formulation of mycoherbicides using a pasta-like process. Biol. Control 1:281-287.

7. Connick, W. J., Jr., Daigle, D. J., Boyette, C. D., Williams, K. S., Vinyard, B. T., and Quimby, P. C., Jr. 1996. Water activity and other factors that affect the viability of Colletotrichum truncatum conidia in wheat flour-kaolin granules ('pesta'). Biocontrol Sci. Technol. 6:277-284.

8. Fravel, D. R., Connick, W. J., Jr., and Lewis, J. A. Formulations of microorganisms control plant diseases. In: Formulation of Microbial Biopesticides, Beneficial Microorganisms and Nematodes. H. D. Burges, ed. Chapman and Hall, London. In press.

9. Fravel, D. R., Lewis, J. A., and Chittams, J. L. 1995. Alginate prill formulations of Talaromyces flavus with organic carriers for biocontrol of Verticillium dahliae. Phytopathology 85:165-168.

10. Griffin, D. M. 1978. Effect of soil moisture on survival and spread of pathogens. Pages 175-197 in: Water Deficits and Plant Growth. T. T. Kozlowski, ed. Academic Press, New York.

11. Hebbar, P. K., Lewis, J. A., Poch, S. M., and Lumsden, R. D. 1996. Fermentation and formulation of mycoherbicidal strains of Fusarium oxysporum. Phytopathology 86:S8-S9.

12. Hebbar, P. K., Lumsden, R. D., Poch, S. M., and Lewis, J. A. 1997. Liquid fermentation to produce biomass of mycoherbicidal strains of Fusarium oxysporum. Appl. Microbiol. Biotechnol. 48:714-719.

13. Helling, C. S., and Doherty, M. A. 1995. Improved method for the analysis of imazapyr in soil. Pestic. Sci. 45:21-26.

14. Hepple, S. 1960. The movement of fungal spores in soil. Trans. Br. Mycol. Soc. 43:73-79.
15. Isensee, A. R., and Sadeghi, A. M. 1992. Laboratory apparatus for studying pesticide leaching in intact soil cores. Chemosphere 25:581-590.

16. Komada, H. 1975. Development of a selective medium for quantitative isolation of Fusarium oxysporum from natural soil. Rev. Plant Prot. Res. 8:115-125.

17. Larkin, R. P., Hopkins, D. L., and Martin, F. N. 1993. Ecology of Fusarium oxysporum f. sp. niveum is soils suppressive and conducive to Fusarium wilt of watermelon. Phytopathology 83:1105-1116.

18. Natsch, A., Keel, C., Troxler, J., Zala, M., Von Albertina, N., and Défago, G. 1996. Importance of preferential flow and soil management in vertical transport of a biocontrol strain of Pseudomonas fluorescens in structured field soil. Appl. Environ. Microbiol. 62:33-40.

19. Nelson, A. J., Elias, K. S., Arévalo, E., and Bailey, B. A. 1996. RAPD analysis of Peruvian isolates of Fusarium oxysporum f. sp. erythroxyli. Phytopathology 86:S68-S69.

20. Nelson, A. J., Elias, K. S., Arévalo G., E., Darlington, L. C., and Bailey, B. A. 1997. Genetic characterization by RAPD analysis of isolates of Fusarium oxysporum f. sp. erythroxyli associated with an emerging epidemic in Peru. Phytopathology 87:1220-1225.

21. Ruddick, S. M., and Williams, S. T. 1972. Studies on the ecology of actinomycetes in soil. V. Some factors influencing the dispersal and adsorption of spores in soil. Soil Biol. Biochem. 4:93-103.

22. Sands, D. C., Ford, E. J., Miller, R. V., Sally, B. K., McCarthy, M. K., Anderson, T. W., Weaver, M. B., Morgan, C. T., Pilgeram, A. L., and Darlington, L. C. 1997. Characterization of a vascular wilt of Erythroxylum coca caused by Fusarium oxysporum f. sp. erythroxyli forma speciales nova. Plant Dis. 81:501-504.

23. Steel, R. G. D., and Torrie, J. H. 1980. Principles and Procedures of Statistics, 2nd ed. McGraw-Hill, Inc., New York.

24. Wallace, H. R. 1978. Dispersal in time and space: Soil pathogens. Pages 181-202 in: Plant Disease, An Advanced Treatise. Vol. II. J. G. Horsfall and E. B. Cowling, eds. Academic Press, New York.

25. Wexler, A., and Hasegawa, S. 1954. Relative humidity-temperature relationships of some saturated salt solutions in the temperature range $0^{\circ}$ to $50^{\circ}$ C. J. Res. Natl. Bur. Stand. 53:19-26.

26. Winston, P. W., and Bates, D. H. 1960. Saturated solutions for the control of humidity in biological research. Ecology 41:232-237. 